Supporting Information for

\title{
Indium-Based Metal-Organic Framework for Efficient Photocatalytic Hydrogen Evolution
}

Chunxiao Lu, Dengke Xiong, Chen Chen, Jiang Wang, Yuxuan Kong, Tian Liu, Shuanglu Ying, and Fei-Yan Yi*

School of Materials Science and Chemical Engineering, Ningbo University, Ningbo, Zhejiang, 315211, P. R. China.

Email: yifeiyan@nbu.edu.cn 


\section{Content List}

\begin{tabular}{|c|c|}
\hline Section S1 & Materials and Characterization \\
\hline Section S2 & Equations \\
\hline Figure S1 & Crystal image for In-MOF \\
\hline Figure S2 & 3D networks along the $a$-axis (a), $b$-axis (b) and $c$-axis (c), respectively. \\
\hline Figure S3 & $\begin{array}{l}\mathrm{N}_{2} \text { and } \mathrm{CO}_{2} \text { adsorption-desorption isotherm and pore size distribution of } \\
\text { In-MOF }\end{array}$ \\
\hline Figure S4 & PXRD patterns In-MOF. \\
\hline Figure S5 & FT-IR of In-MOF crystals and $\mathrm{H}_{4} \mathrm{~L}$ ligands \\
\hline Figure S6 & $\begin{array}{l}\text { PXRD patterns and FT-IR spectra of In-MOF catalysts immersed in } \\
\text { different solvents }\end{array}$ \\
\hline Figure S7 & Thermogravimetric analysis curve of In-MOF \\
\hline Figure S8 & The $(\mathrm{Ah} v)^{1 / 2} \mathrm{vs} \mathrm{h} v(\mathrm{eV})$ relationship diagram of In-MOF. \\
\hline Figure S9 & $\begin{array}{l}\mathrm{H}_{2} \text { evolution efficiency trend vs. irradiation time for five different } \\
\text { samples under same condition. }\end{array}$ \\
\hline Figure S10 & The AQY curves and UV/Vis reflectance spectrum of In-MOF. \\
\hline Figure S11 & XRD patterns of In-MOF before and after $\mathrm{H}_{2}$ evolution. \\
\hline Figure S12 & $\begin{array}{l}\text { (a) FT-IR spectra of TEOA, In-MOF before and after } \mathrm{H}_{2} \text { evolution. (b) } \\
\text { Raman spectra of In-MOF before and after } \mathrm{H}_{2} \text { evolution. }\end{array}$ \\
\hline Table S1 & Summary of crystal data and refinement results for In-MOF \\
\hline Table S2 & Selected bond length $(\AA)$ and bond angle $\left(^{\circ}\right)$ for In-MOF \\
\hline Table S3 & $\begin{array}{l}\text { Comparison of In-MOF in this work and some other reported MOFs- } \\
\text { based photocatalysts }\end{array}$ \\
\hline $\operatorname{Re}$ & \\
\hline
\end{tabular}




\section{Section S1. Materials and Characterization}

In this work, 3,3',5,5'-azoxybenzenetetracarboxylic acid was synthesized based on previous reports. ${ }^{1-3}$ Other reagents and chemicals are purchased commercially, and further purification is not required. Fourier transform infrared (FT-IR) spectra of the samples were performed in a Nicolet 6700 FT-IR spectrometer using $\mathrm{KBr}$ pellets in the wavenumber range of $400-4000 \mathrm{~cm}^{-1}$. The purity of sample was characterized by powder X-ray diffractometer on a Bruker D8 diffractometer using $\mathrm{Cu} \mathrm{K \alpha}$ radiation $(\lambda=1.5418 \AA)$. The specific surface area and pore size analysis of the compound were measured on the Micromeritics ASAP 2460 device (the degassing time of the compound was 8 hours before the test, and the degassing temperature was $120^{\circ} \mathrm{C}$ ). Thermogravimetric analysis (TGA) was tested on a Netzsch STA 2500 equipment. The compound was heated from $30{ }^{\circ} \mathrm{C}$ to $900{ }^{\circ} \mathrm{C}$ in a nitrogen atmosphere at a heating rate of 5 ${ }^{\circ} \mathrm{C} \cdot \mathrm{min}^{-1}$. The UV-Vis absorption spectrum was measured by Shimadzu UV-2600 spectrometer in the wavelength range of $200 \mathrm{~nm}-800 \mathrm{~nm}$. Photoluminescence spectroscopy was performed on RF-6000. Use the PerfectLight, Labsolar-IIIAG photocatalytic system device to perform photocatalytic $\mathrm{H}_{2}$ production under the conditions of a $300 \mathrm{~W}$ xenon lamp (PLS-SXE 300C) for 4 hours. In the photocatalytic process, $\mathrm{H}_{2}$ fuel evolution was detected by gas chromatograph (GC9200, TCD) online monitoring per hour. Raman spectra were obtained on a Raman spectrometer from thermo Scientific with a $532 \mathrm{~nm}$ lase source. All samples and liquids are transferred in a fume cupboard and stored in glass vials containing mother liquor unless otherwise noted.

\section{Section S2. Equations}

\section{S2.1 Obtain the band gap $\left(E_{g}\right)$ from the UV-Vis Absorption Spectra}


The band gap is calculated by the following formula:

$$
\left.(\alpha \mathrm{h} v)^{1 / 2}=\left(\mathrm{h} v-\mathrm{E}_{\mathrm{g}}\right) \quad \text { (equation } \mathrm{S} 1\right)
$$

Among them, $\alpha$ represents the light absorption coefficient; $h$ is Planck's constant; $v$ is the frequency; $\mathrm{E}_{\mathrm{g}}$ is the band gap value of semiconductor. ${ }^{4,5}$

The relationship between the absorbance (A) and the light absorption coefficient $(\alpha)$ is:

$$
\mathrm{A}=\mathrm{K} \alpha \quad \text { (equation } \mathrm{S} 2 \text { ) }
$$

Among them, $\mathrm{K}$ is a constant. Taking Equation S2 into Equation S1, Equation S3 can be obtained:

$$
(\mathrm{Ah} v / \mathrm{K})^{1 / 2}=\left(\mathrm{h} v-\mathrm{E}_{\mathrm{g}}\right) \quad(\text { equation } \mathrm{S} 3)
$$

Since the $\mathrm{K}$ does not affect $\mathrm{E}_{\mathrm{g}}$, it was regarded as 1 here. Taking (Ahv) ${ }^{1 / 2}$ as the ordinate and $\mathrm{h} v$ as the abscissa, the Tauc plot of In-MOF can be obtained (Figure S9).

\section{S2.2 Mott-Schottky measurement}

The plot can depict the relationship between capacitance $(C)$ and applied potential $\left(V_{a}\right)$ at a fixed frequency. The formula is as follows:

$$
\left.1 / \mathrm{C}^{2}=\left(2 / \mathrm{e} \varepsilon \varepsilon_{0} \mathrm{~N}_{\mathrm{d}}\right)\left[\mathrm{V}_{\mathrm{a}}-\mathrm{V}_{\mathrm{fb}}-\mathrm{kT} / \mathrm{e}\right] \quad \text { (equation } \mathrm{S} 4\right)
$$

$\mathrm{C}$ is the capacitance of the space charge layer; e is the electronic charge, $\varepsilon$ is the dielectric constant of semiconductors; $\varepsilon_{o}$ is the permittivity of free space; and $N_{d}$ is the density of charge carrier $\left(\mathrm{cm}^{-3}\right), \mathrm{V}_{\mathrm{a}}$ is the applied potential, $\mathrm{V}_{\mathrm{fb}}$ is the flat band potential $(\mathrm{V}), \mathrm{k}$ is Boltzmann 
constant, and $\mathrm{T}$ is the temperature in Kelvin. The linear regressions with respect to $1 / \mathrm{C}^{2}$ and $\mathrm{V}_{\mathrm{a}}$ at different frequencies were used to evaluate the value of $\mathrm{V}_{\mathrm{fb}}$.

\section{S2.3 Apparent quantum yield measurement}

The apparent quantum yield (AQY) of hydrogen evolution was measured using monochromatic light obtained by band-pass filters of 365 and $420 \mathrm{~nm}$. The calculation of AQY is as follows.

$$
\eta=\frac{2 \times \mathrm{M} \times \mathrm{N}_{A} \times \mathrm{h} \times \mathrm{c}}{\mathrm{S} \times \mathrm{P} \times \mathrm{t} \times \lambda} \times 100 \%
$$

Where $\mathrm{M}$ is the amount of the evolution $\mathrm{H}_{2}(\mathrm{~mol}), \mathrm{N}_{\mathrm{A}}$ is Avogadro's constant $\left(6.022 \times 10^{23}\right.$ $\left.\mathrm{mol}^{-1}\right), \mathrm{h}$ is the Planck constant $\left(6.626 \times 10^{-34} \mathrm{~J} \cdot \mathrm{s}\right), \mathrm{c}$ is the speed of light $\left(3 \times 10^{8} \mathrm{~m} \cdot \mathrm{s}^{-1}\right), \mathrm{S}$ is the irradiation area of incident light $\left(\mathrm{cm}^{2}\right), \mathrm{P}$ is the intensity of incident light $\left(\mathrm{W} \cdot \mathrm{cm}^{-2}\right), \mathrm{t}$ is the photoreaction time (s), $\lambda$ is the wavelength of monochromatic light $(\mathrm{m})$. In this work, the evolution $\mathrm{H}_{2}$ amount is 101.77 and $20.45 \mu \mathrm{mol}$ under 365 and $420 \mathrm{~nm}$ with the intensity of incident light of 0.018 and $0.015 \mathrm{~W} \mathrm{~cm}^{-2}$. The irradiation area and photoreaction time are $\mathrm{S}=$ $21.2 \mathrm{~cm}^{2}$ and $\mathrm{t}=10800 \mathrm{~s}$, respectively. 


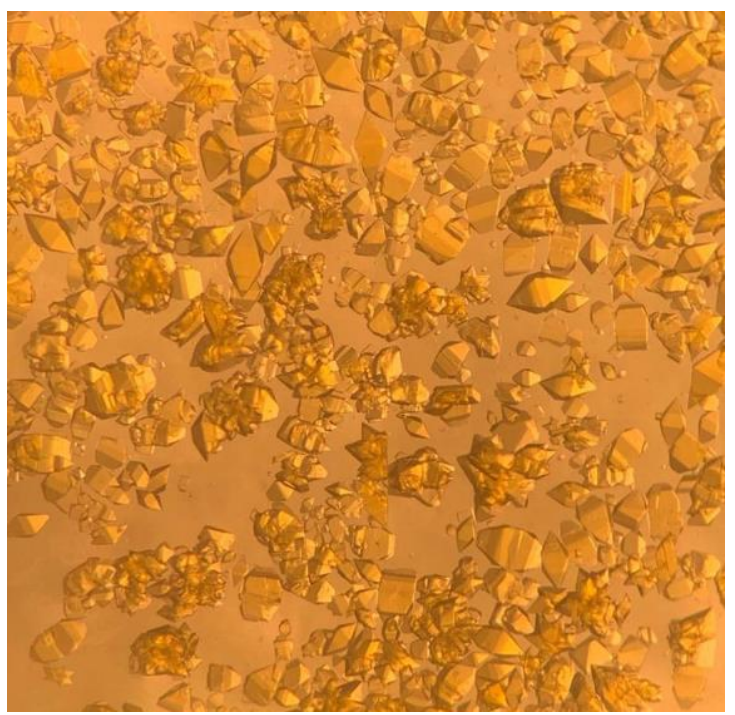

Figure S1. Crystal image for In-MOF.

(a)

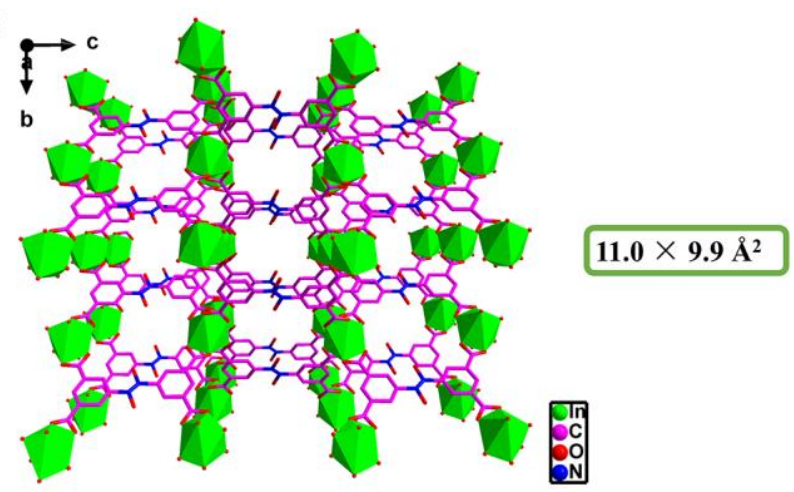

(b)

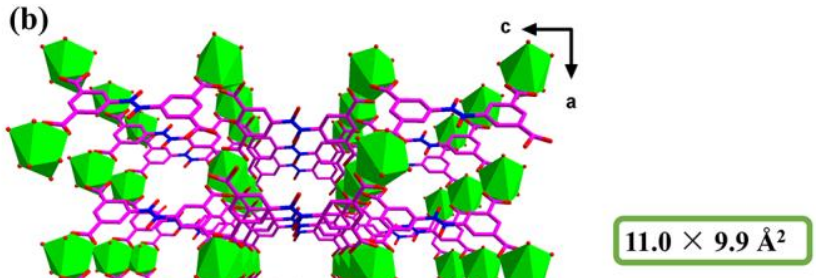




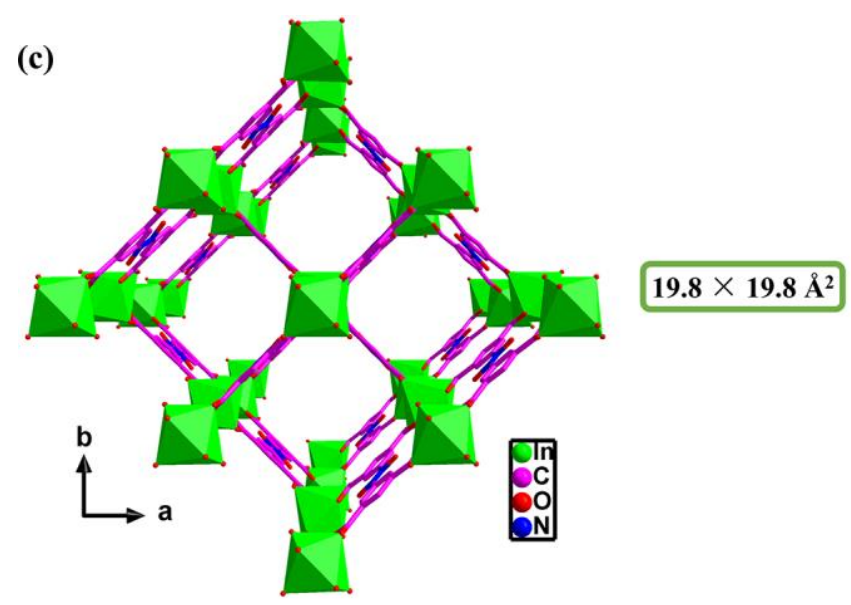

Figure S2. 3D networks along the $a$-axis (a), $b$-axis (b) and $c$-axis (c), respectively.

(a)

(c)
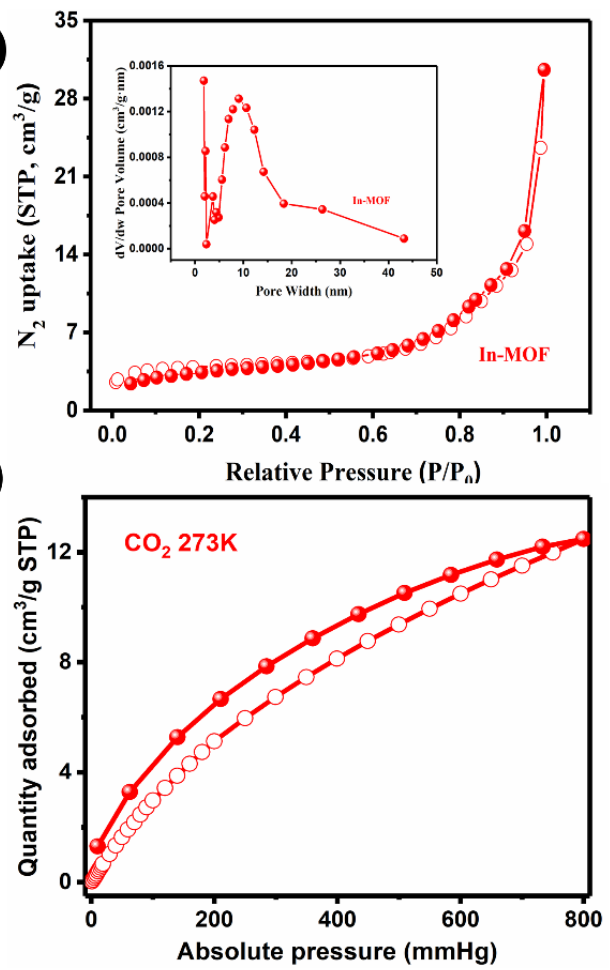

(b)

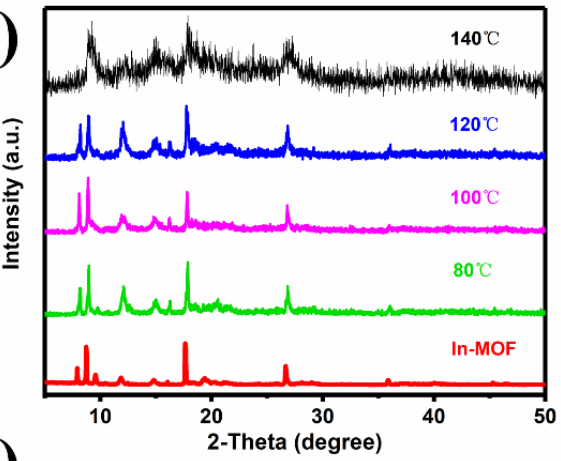

(d)

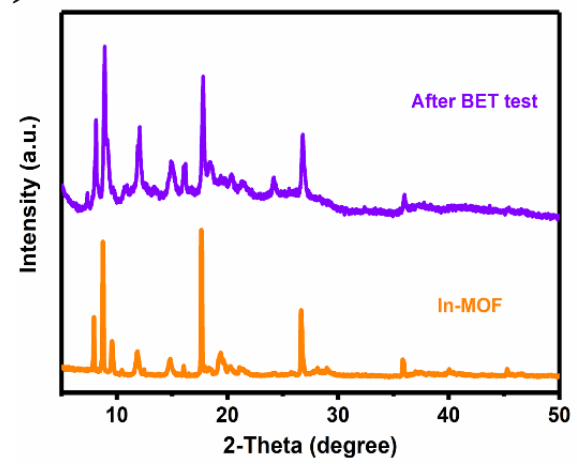

Figure S3. (a) $\mathrm{N}_{2}$ adsorption (empty) and desorption (solid) isotherm and pore size distribution of In-MOF. (b) PXRD patterns of vacuum heating at different temperatures for $2 \mathrm{~h}$. (c) $\mathrm{CO}_{2}$ adsorption (empty) and desorption (solid) isotherms for In-MOF at 273K. Before the 
measurements, the sample was dried through the "degas" function of the instrument for $24 \mathrm{~h}$ at $80^{\circ} \mathrm{C}$. (d) PXRD patterns for In-MOF before and after $\mathrm{CO}_{2}$ adsorption test.

Before gas adsorption test, In-MOF sample was pre-treated via following process. In-MOF sample of $200 \mathrm{mg}$ was immersed into anhydrous methanol for 3 days. The methanol solution was refreshed four times during the exchange every day. Then, similar immersion was utilized to treat the sample with dichloromethane to remove methanol molecules. Last, the wet sample was obtained by centrifuged, and dried under vacuum at $120{ }^{\circ} \mathrm{C}$ for $8 \mathrm{~h}$. The heating temperature of $120{ }^{\circ} \mathrm{C}$ was determined based on PXRD results of In-MOF samples after being heat-treated at different temperatures of $80{ }^{\circ} \mathrm{C}, 100{ }^{\circ} \mathrm{C}, 120{ }^{\circ} \mathrm{C}$, and $140{ }^{\circ} \mathrm{C}$ under vacuum, respectively. As shown in Figure S3, it is very clear that the PXRD peaks of In-MOF samples after being treated at $80{ }^{\circ} \mathrm{C}, 100{ }^{\circ} \mathrm{C}, 120{ }^{\circ} \mathrm{C}$ are identical to those of initial In-MOF sample, demonstrating its robustness of activated In-MOF sample. However, it is a pity that as-synthesized In-MOF exhibits a relatively small Brunauer-Emmett-Teller (BET) and Langmuir surface areas of 14.73 $\mathrm{m}^{2} \mathrm{~g}^{-1}$ and $70.97 \mathrm{~m}^{2} \mathrm{~g}^{-1}$, respectively, for $\mathrm{N}_{2}$ gas sorption, as shown in Figure S3a. As previous literature reported, some pristine MOFs with large channels also exhibited relatively low BET results. ${ }^{6-8}$ The relatively low $\mathrm{N}_{2}$ sorption amount for the materials in our work and previous reports may be due to the mismatched sizes and weak interaction between $\mathrm{N}_{2}$ molecule and channel. In order to verify the above speculation, $\mathrm{CO}_{2}$ adsorption and desorption experiment has been performed at $273 \mathrm{~K}$. As shown in Figure S3, $\mathrm{CO}_{2}$ adsorption value of $\mathrm{In}-\mathrm{MOF}$ can be up to $23.90 \mathrm{~m}^{2} \mathrm{~g}^{-1}$. The PXRD result of In-MOF sample after $\mathrm{CO}_{2}$ adsorption test shows that no obvious differences could be observed, further indicating that In-MOF skeleton can be well maintained. 


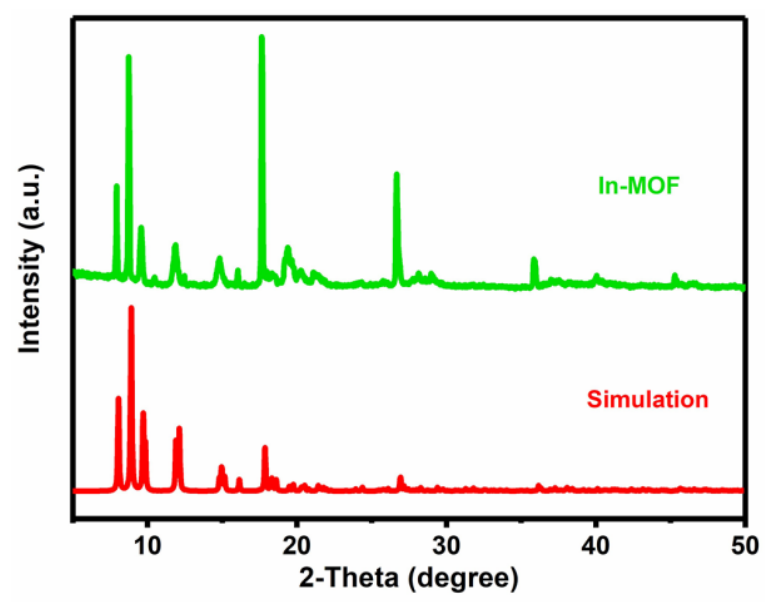

Figure S4. PXRD patterns In-MOF.

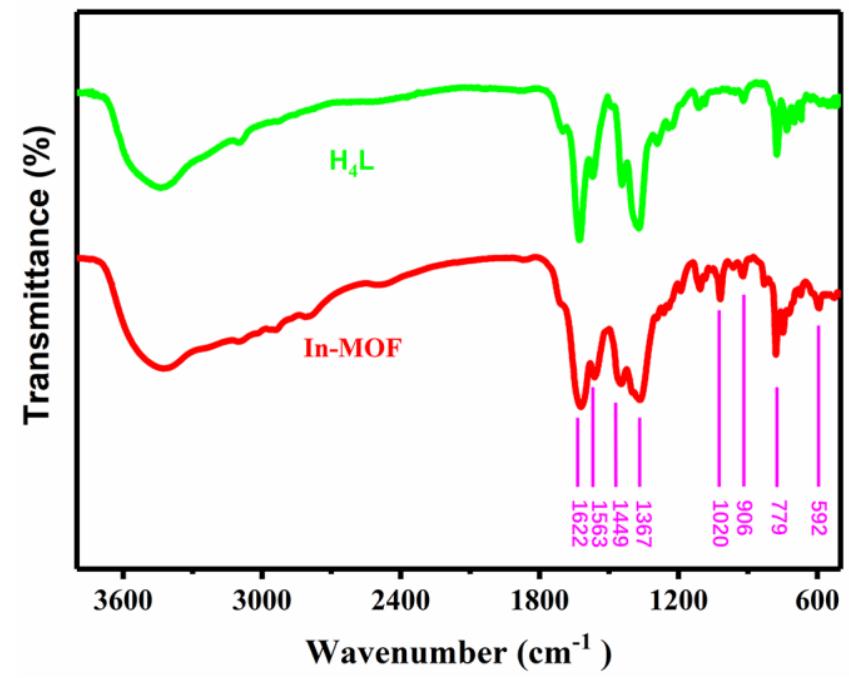

Figure S5. FT-IR spectra of In-MOF and free $\mathrm{H}_{4} \mathrm{~L}$ ligand. 

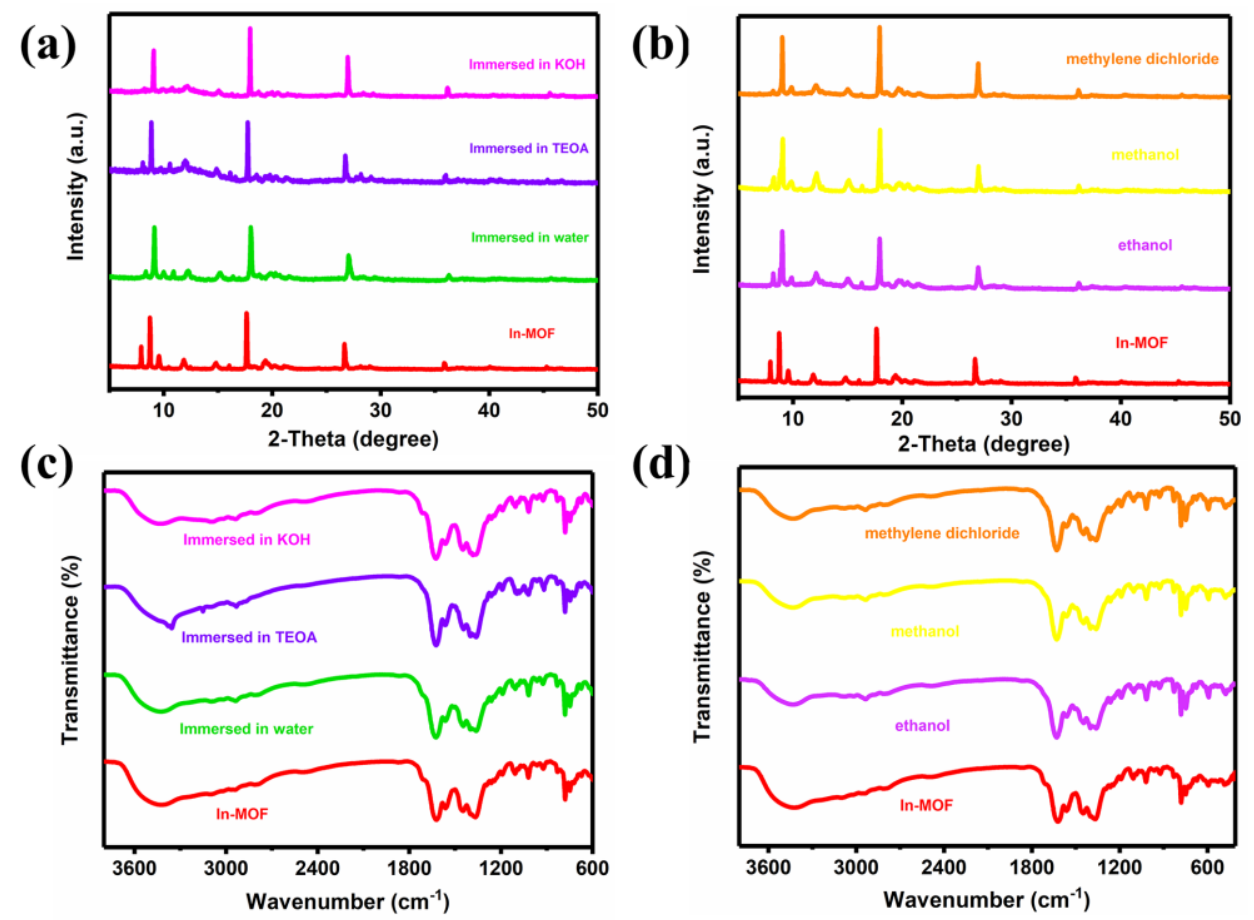

(d)

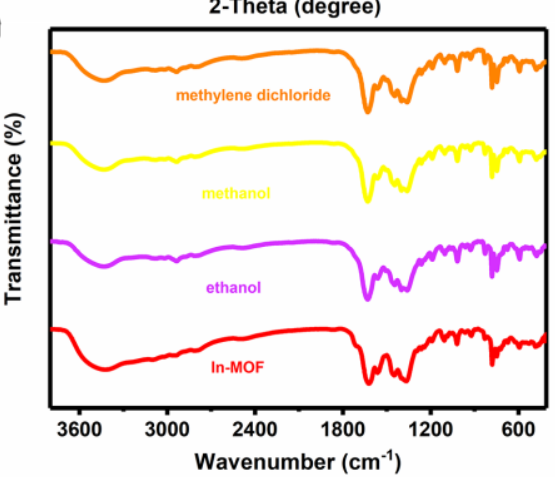

Figure S6. PXRD patterns and FT-IR spectra of In-MOF immersed in different solvents for $2 \mathrm{~h}$ including water, TEOA, methylene dichloride, methanol, and ethanol, and in $\mathrm{KOH}(\mathrm{pH}=13)$ for $12 \mathrm{~h}$.

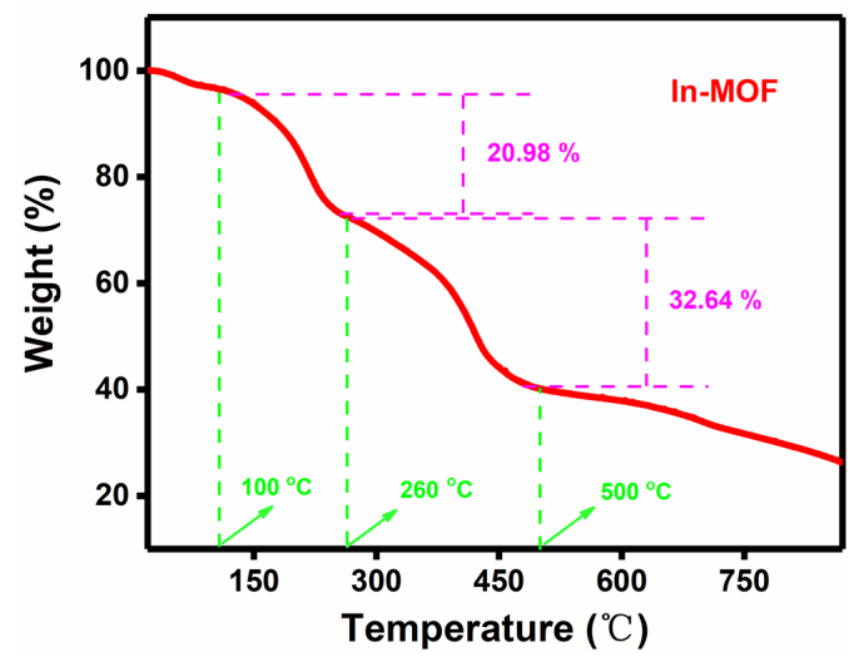

Figure S7. TGA curve of In-MOF. 


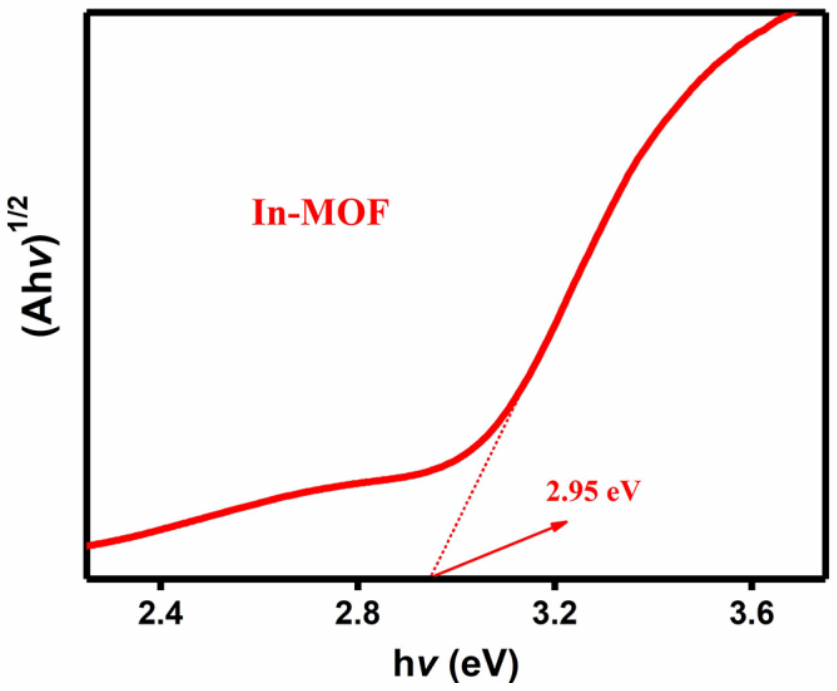

Figure S8. The $(\mathrm{Ah} v)^{1 / 2} \mathrm{vs} \mathrm{h} v(\mathrm{eV})$ relationship diagram of In-MOF.

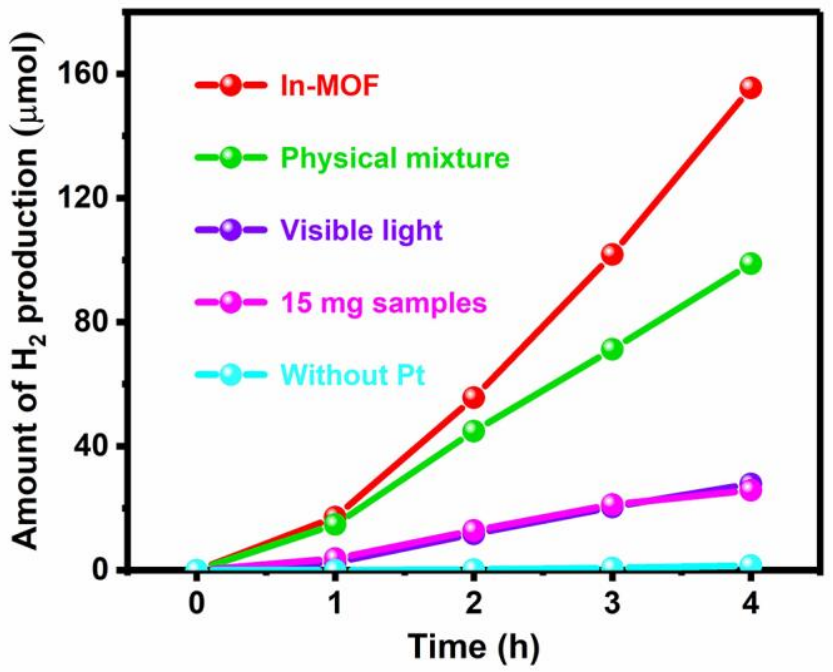

Figure S9. $\mathrm{H}_{2}$ evolution efficiency trend vs. irradiation time for five different samples under same condition. 


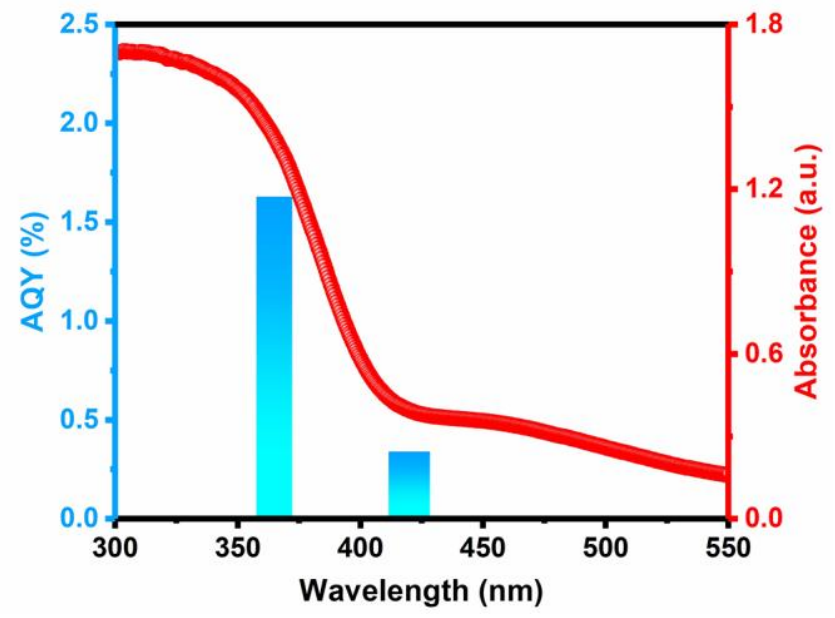

Figure S10. The AQY curves and UV/Vis reflectance spectrum of In-MOF.

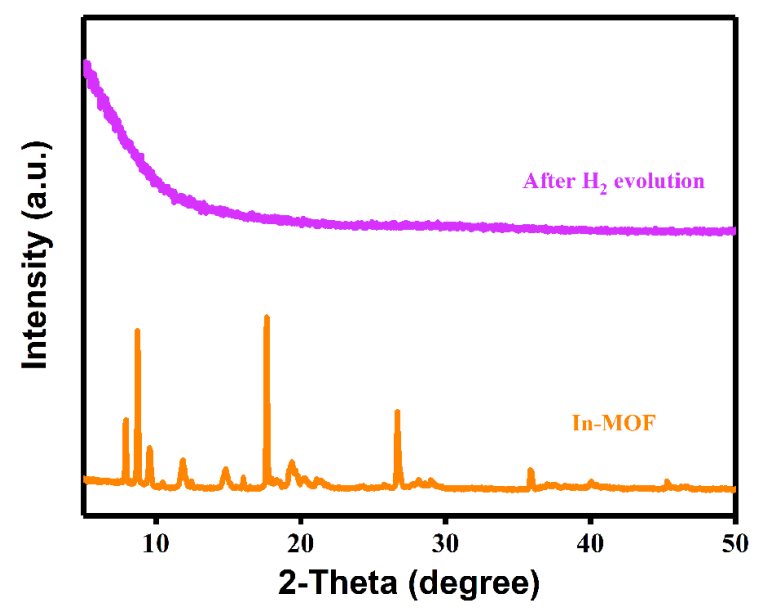

Figure S11. XRD patterns of In-MOF before and after $\mathrm{H}_{2}$ evolution. 

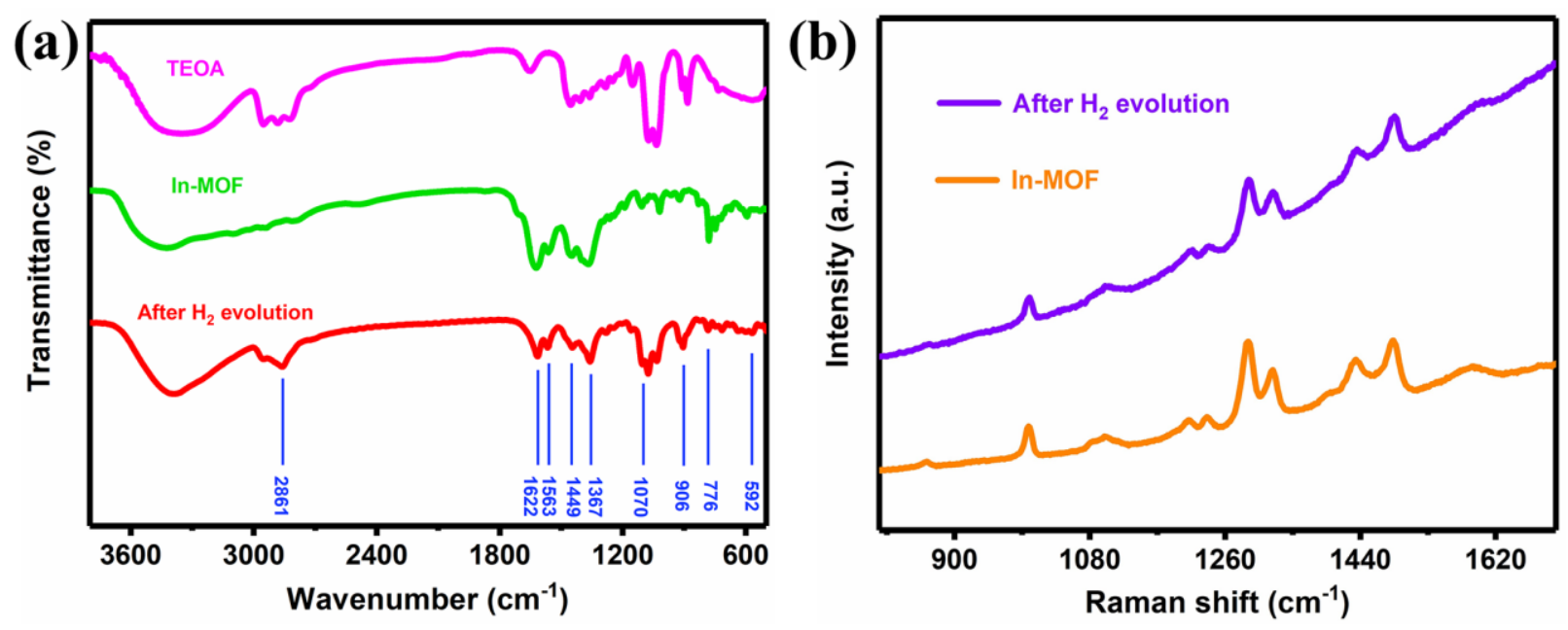

Figure S12. (a) FT-IR spectra of TEOA, In-MOF before and after $\mathrm{H}_{2}$ evolution. (b) Raman spectra of In-MOF before and after $\mathrm{H}_{2}$ evolution. 
Table S1. Summary of crystal data and refinement results for In-MOF.

\begin{tabular}{|l|l|}
\hline Compound & In-MOF \\
\hline CCDC number & 2101787 \\
\hline temperature $(\mathrm{K})$ & $296(2)$ \\
\hline empirical formula & $\mathrm{C}_{16} \mathrm{H}_{6} \mathrm{InN}_{2} \mathrm{O}_{10}$ \\
\hline formula weight & 501.05 \\
\hline crystal system & monoclinic \\
\hline space group & $\mathrm{C} 2 / \mathrm{c}$ \\
\hline a $(\AA)$ & $14.001(7)$ \\
\hline b $(\AA)$ & $14.024(7)$ \\
\hline c $(\AA)$ & $21.917(11)$ \\
\hline a $/^{\circ}$ & 90 \\
\hline$\beta /{ }^{\circ}$ & $91.479(11)$ \\
\hline$\gamma /{ }^{\circ}$ & 90 \\
\hline V $\left(\AA^{3}\right)$ & $4302(4)$ \\
\hline$Z$ & 4 \\
\hline calculated density & 0.774 \\
\hline F(000) & 980 \\
\hline adsorption coefficient, mm ${ }^{-1}$ & 0.575 \\
\hline goodness-of-fit on $\mathrm{F}^{2}$ & 1.036 \\
\hline reflections collected/unique & $9573 / 2755\left[\mathrm{R}_{\text {int }}=0.0715\right]$ \\
\hline final R indexes [I $>2 \sigma(\mathrm{I})]$ & $\mathrm{R}_{1}=0.1468, w \mathrm{R}_{2}=0.3806$ \\
\hline final R indexes (all data) & $\mathrm{R}_{1}=0.1631, w \mathrm{R}_{2}=0.3880$ \\
\hline completeness, $\%$ & 89 \\
\hline
\end{tabular}


Table S2. Selected bond length $(\AA)$ and bond angle $\left({ }^{\circ}\right)$ for In-MOF.

\begin{tabular}{|l|l|l|l|}
\hline In1-O2A & $2.15(2)$ & O2-In1-O1 & $52.5(6)$ \\
\hline In1-O2 & $2.15(2)$ & O2A-In1-O1A & $52.5(6)$ \\
\hline In1-O4B & $2.166(13)$ & O4B-In1-O3B & $53.3(5)$ \\
\hline In1-O4C & $2.166(13)$ & O4C-In1-O3C & $53.3(5)$ \\
\hline In1-O1 & $2.182(17)$ & O2A-In1-O1 & $82.1(6)$ \\
\hline In1-O1A & $2.182(17)$ & O1-In1-O1A & $121.0(9)$ \\
\hline In1-O3B & $2.488(11)$ & O2-In1-O4C & $88.7(6)$ \\
\hline In1-O3C & $2.488(11)$ & O2A-In1-O2 & $81.3(8)$ \\
\hline C1-O2 & $1.16(3)$ & O4B-In1-O1A & $124.0(6)$ \\
\hline C1-O1 & $1.27(3)$ & O1A-In1-O3B & $85.7(6)$ \\
\hline C1-C2 & $1.43(3)$ & O2A-In1-O4B & $88.7(6)$ \\
\hline C5-O4 & $1.19(2)$ & O2A-In1-O3B & $92.0(5)$ \\
\hline C3-C4 & $1.31(2)$ & O2-In1-O3B & $167.7(5)$ \\
\hline C5-O3 & $1.25(2)$ & O4B-In1-O3C & $89.1(5)$ \\
\hline C7-N1 & $1.49(3)$ & O3B-In1-O3C & $96.4(7)$ \\
\hline O3-In1D & $2.488(11)$ & O4B-In1-O4C & $125.2(8)$ \\
\hline O4-In1D & $2.166(13)$ & N1E-N1-O5 & $115(5)$ \\
\hline O5-N1 & $1.34(7)$ & O5-N1-C7 & $116(4)$ \\
\hline N1-N1E & $1.03(4)$ & N1E-N1-C7 & $129(3)$ \\
\hline
\end{tabular}

Symmetry transformations used to generate equivalent atoms: $\mathrm{A}-\mathrm{x}+1, \mathrm{y},-\mathrm{z}+3 / 2 ; \mathrm{B} x+1 / 2$, $\mathrm{y}+1 / 2, \mathrm{z} ; \mathrm{C}-\mathrm{x}+1 / 2, \mathrm{y}+1 / 2,-\mathrm{z}+3 / 2 ; \mathrm{D} \mathrm{x}-1 / 2, \mathrm{y}-1 / 2, \mathrm{z} ; \mathrm{E}-\mathrm{x}+1 / 2,-\mathrm{y}+1 / 2,-\mathrm{z}+2$. 
Table S3. The Comparison among In-MOF in this work and some other reported MOFs-based photocatalysts.

\begin{tabular}{|c|c|c|c|c|c|}
\hline Photoca talysts & $\begin{array}{l}\text { Weight } \\
(\mathrm{mg})\end{array}$ & Cocatalyst & \begin{tabular}{|l}
$\mathrm{H}_{2}$ rate \\
$\left(\mu \mathrm{molg}^{-1} \mathrm{~h}^{-1}\right)$ \\
\end{tabular} & Irradiation & Ref. \\
\hline \multirow{2}{*}{$\mathrm{UIO}-66\left(\mathrm{NH}_{2}\right)$} & \multirow{2}{*}{45} & $1 \mathrm{wt} \% \mathrm{Pt}$ & 924 & \multirow{2}{*}{$370 \mathrm{~nm}$} & \multirow{2}{*}{9} \\
\hline & & absence & 178 & & \\
\hline CPM-2-NH 2 & 100 & $1 \mathrm{wt} \% \mathrm{Pt}$ & 20 & UV & 10 \\
\hline$\left[\mathrm{Gd}(\mathrm{abtc})\left(\mathrm{H}_{2} \mathrm{O}\right)_{2}(\mathrm{OH})_{2}\right] \cdot 2 \mathrm{H}_{2} \mathrm{O}$ & \multirow[b]{2}{*}{50} & absence & 154.2 & \multirow[b]{2}{*}{ UV-Vis } & \multirow[b]{2}{*}{11} \\
\hline $\begin{array}{l}\mathrm{Ag}(1.5)- \\
{\left[\mathrm{Gd}(\mathrm{abtc})\left(\mathrm{H}_{2} \mathrm{O}\right)_{2}(\mathrm{OH})_{2}\right] \cdot 2 \mathrm{H}_{2} \mathrm{O}}\end{array}$ & & $1.5 \mathrm{wt} \% \mathrm{Ag}$ & 212 & & \\
\hline $\mathrm{Ru}_{2}(p-\mathrm{BDC})_{2}$ & 10 & absence & 1610 & Visible-light & 12 \\
\hline $\begin{array}{l}\left.\mathrm{Ln}_{2} \mathrm{Cu}_{5}(\mathrm{OH})_{2}(\mathrm{pydc})_{6}\left(\mathrm{H}_{2} \mathrm{O}\right)_{8}\right] \cdot \mathrm{I} \\
8 ; \mathrm{Ln}=\mathrm{Sm}, \mathrm{Eu}, \mathrm{Gd}, \text { or } \mathrm{Tb}\end{array}$ & 100 & absence & 2262.8 & UV & 13 \\
\hline AlTCS-1 & 10 & absence & 50 & Visible-light & 14 \\
\hline Al-ATA-Ni MOF & 30 & absence & 1200 & UV-Vis & 15 \\
\hline $\mathrm{Co}_{2}(\mathrm{HL})_{2}(\mathrm{DMF})_{2} \mathrm{H}_{2} \mathrm{O}$ & 4 & $\begin{array}{l}\begin{array}{l}\mathrm{Ru}(\mathrm{bpy})_{3} \mathrm{Cl}_{2}(4 \quad \mathrm{mg}) \\
\text { photosensitizer }\end{array} \\
\end{array}$ & 1778 & Visible-light & 16 \\
\hline $\mathrm{PCN}-415-\mathrm{NH}_{2}$ & 5 & $50 \mu \mathrm{g}$ of $\mathrm{Pt}$ & 594 & $\mathrm{UV}-\mathrm{Vis}$ & 17 \\
\hline$\left\{\mathrm{Zn}_{2}(\mathrm{OPE}-\mathrm{TC} 1)\right\}_{\mathrm{n}}$ & 5 & absence & 600 & Visible-light & \multirow{2}{*}{18} \\
\hline SRG2@ $\left\{\mathrm{Zn}_{2}(\mathrm{OPE}-\mathrm{TC} 1)\right\}_{\mathrm{n}}$ & 5 & absence & 1080 & UV-Vis & \\
\hline Bi-TBAPy & 30 & $2 \mathrm{wt} \% \mathrm{Pt}$ & 140 & Visible-light & 19 \\
\hline$\left[\mathrm{Co}\left(\mathrm{C}_{30} \mathrm{H}_{16} \mathrm{O}_{8}\right)-\left(\mathrm{C}_{10} \mathrm{H}_{8} \mathrm{~N}_{2}\right)\right]_{\mathrm{n}}$ & 5 & $\begin{array}{l}\text { Fluorescein }(2.0 \mathrm{mM}) \text { as } \\
\text { photosensitizer }\end{array}$ & 6000 & Visible-light & 20 \\
\hline $\mathrm{Co}_{3}-\mathrm{XL}$ & 100 & $2 \mathrm{wt} \% \mathrm{Pt}$ & 23.05 & $\lambda \geq 320 \mathrm{~nm}$ & 21 \\
\hline$\left[\mathrm{Cu}_{2} \mathrm{I}_{2}(\mathrm{BPEA})\right](\mathrm{DMF})_{4}$ & 15 & absence & 4216 & UV-Vis & 22 \\
\hline \multirow[b]{2}{*}[\mathrm{Hg}(\mathrm{Bpbp})(\mathrm{SCN})_{2}]{$_{\mathrm{n}}$} & \multirow[b]{2}{*}{25} & absence & 280 & \multirow[b]{2}{*}{ AM1.5 } & \multirow[b]{2}{*}{23} \\
\hline & & $\begin{array}{|ll|}0.05 & \mathrm{mM} \text { chloroplatinic } \\
\text { acid } & \\
\end{array}$ & 1620 & & \\
\hline $\begin{array}{l}\mathrm{H}_{15}\left[\mathrm{Na}_{0.5} \mathrm{Cu}_{2}(\mathrm{~L} 1)(\mathrm{L} 2)\left(\mathrm{H}_{2} \mathrm{O}\right)\right] \cdot \\
5.5 \mathrm{H}_{2} \mathrm{O}\end{array}$ & 4 & $\begin{array}{l}\text { Fluorescein }(10 \mu \mathrm{M}) \text { as } \\
\text { photosensitizer }\end{array}$ & 4650 & Visible light & 24 \\
\hline $\mathrm{Pb}_{3} \mathrm{ttc}_{2} \cdot 2 \mathrm{H}_{2} \mathrm{O}$ & 3 & $\mathrm{~K}_{2} \mathrm{PtCl}_{4}(300 \mu \mathrm{M}, 1.0 \mathrm{~mL})$ & 25.5 & Visible light & 25 \\
\hline USTC-8(In) & 10 & $1.5 \mathrm{wt} \% \mathrm{Pt}$ & 341.3 & UV-Vis & 26 \\
\hline \multirow{3}{*}{$\mathrm{POTi}_{12} \mathrm{Cr}_{6}$} & \multirow{3}{*}{20} & \multirow{3}{*}{$1 \mathrm{~mL}$ of platinum colloid } & 147.86 & AM1.5 & \multirow{3}{*}{27} \\
\hline & & & 68.2 & Visible light & \\
\hline & & & 53.6 & NIR light & \\
\hline$\left[\mathrm{Dy}_{2}(\mathrm{abtc})\left(\mathrm{H}_{2} \mathrm{O}\right)_{2}(\mathrm{OH})_{2}\right] 2 \mathrm{H}_{2} \mathrm{O}$ & 50 & $0.8 \mathrm{wt} \% \mathrm{Pt}$ & 21.53 & UV-Vis & 28 \\
\hline MIL-167 & 30 & absence & 7.7 & UV & 29 \\
\hline \multirow{2}{*}{ Ti-MOF-NH 2} & \multirow{2}{*}{10} & \multirow{2}{*}{$\begin{array}{l}0.039 \mathrm{M} \\
\mathrm{H}_{2} \mathrm{PtCl}_{6} \quad \text { methanol } \\
\text { solution }(0.55 \mathrm{~mL})\end{array}$} & 11.7 & UV & \multirow{2}{*}{30} \\
\hline & & & 3.67 & Visible light & \\
\hline \multirow{2}{*}{ In-MOF } & \multirow{2}{*}{$\mathbf{5 0}$} & $1 \mathrm{wt} \% \mathrm{Pt}$ & 777.65 & \multirow{2}{*}{$\mathbf{U V}$} & \multirow{2}{*}{$\begin{array}{l}\text { This } \\
\text { work }\end{array}$} \\
\hline & & absence & 7.60 & & \\
\hline
\end{tabular}




\begin{tabular}{l|l|l|l|l|l}
\hline & & $1 \mathrm{wt} \% \mathrm{Pt}$ & 139.40 & $\begin{array}{l}\text { Visible } \\
\text { light }\end{array}$ & \\
\hline
\end{tabular}

\section{REFERENCES}

(1) Wang, S. X.; Wang, X. M.; Li, L. J.; Advincula, R. C. Design, synthesis, and photochemical behavior of poly (benzyl ester) dendrimers with azobenzene groups throughout their architecture. J. Org. Chem. 2004, 69 (26), 9073-9084.

(2) Wu, M. K.; Yi, F. Y.; Fang, Y.; Xiao, X. W.; Wang, S. C.; Pan, L. Q.; Zhu, S. R.; Tao, K.; Han, L. An ultrastable metal-organic framework with open coordinated sites realizing selective separation toward cationic dyes in aqueous solution. Cryst. Growth Des. 2017, 17 (10), 54585464.

(3) Gu, M. L.; Wang, S. C.; Chen, C.; Xiong, D. K.; Yi, F. Y. Iron-Based Metal-Organic Framework System as an Efficient Bifunctional Electrocatalyst for Oxygen Evolution and Hydrogen Evolution Reactions. Inorg. Chem. 2020, 59 (9), 6078-6086.

(4) Tauc, J.; Grigorovici, R.; Vancu, A. Optical properties and electronic structure of amorphous germanium. Phys Status Solidi B. 1966, 15 (2), 627-637.

(5) Davis, E. A.; Mott, N. F. Conduction in non-crystalline systems V. Conductivity, optical absorption and photoconductivity in amorphous semiconductors. Philos Mag. 1970, 22 (179), 0903-0922.

(6) Yi, F.-Y.; Wang, S.-C.; Gu, M.; Zheng, J.-Q.; Han, L. Highly selective luminescent sensor for $\mathrm{CCl}_{4}$ vapor and pollutional anions/cations based on a multi-responsive MOF. J. Mater. Chem. C 2018, 6, 2010-2018; 
(7) Wang, G.; Sun, Q.; Liu, Y.; Huang, B.; Dai, Y.; Zhang, X.; Qin, X. A Bismuth-Based Metal-Organic Framework as an Efficient Visible-Light-Driven Photocatalyst. Chem. Eur. J. 2015, 21, 2364-2367;

(8) Xiao, Y.; Qi, Y.; Wang, X.; Wang, X.; Zhang, F.; Li, C. Visible-Light-Responsive 2D Cadmium-Organic Framework Single Crystals with Dual Functions of Water Reduction and Oxidation. Adv. Mater. 2018, 30, 1803401.

(9) Gomes Silva, C.; Luz, I.; Llabres i Xamena, F. X.; Corma, A.; García, H. Water stable Zrbenzenedicarboxylate metal-organic frameworks as photocatalysts for hydrogen generation. Chem. - Eur. J. 2010, $16(36), 11133-11138$.

(10) Zheng, S. T.; Zuo, F.; Wu, T.; Irfanoglu, B.; Chou, C.; Nieto, R. A.; Feng, P. Y.; Bu, X. H. Cooperative Assembly of Three-Ring-Based Zeolite-Type Metal-Organic Frameworks and Johnson-Type Dodecahedra. Angew. Chem., Int. Ed. 2011, 50 (8), 1849-1852.

(11) Sun, X. J.; Yu, Q.; Zhang, F. M.; Wei, J. Z.; Yang, P. A dye-like ligand-based metalorganic framework for efficient photocatalytic hydrogen production from aqueous solution. Catal Sci Technol. 2016, 6 (11), 3840-3844.

(12) Kataoka, Y.; Sato, K.; Miyazaki, Y.; Masuda, K.; Tanaka, H.; Naito, S.; Mori, W. Photocatalytic hydrogen production from water using porous material $\left[\mathrm{Ru}_{2}(\mathrm{p}-\mathrm{BDC})_{2}\right]_{\mathrm{n}}$. Energy Environ. Sci. 2009, 2 (4), 397-400.

(13) Hu, X. L.; Sun, C. Y.; Qin, C.; Wang, X. L.; Wang, H. N.; Zhou, E. L.; Li, W. E.; Su, Z. M. Iodine-templated assembly of unprecedented $3 \mathrm{~d}-4 \mathrm{f}$ metal-organic frameworks as photocatalysts for hydrogen generation. Chem. Commun. 2013, 49 (34), 3564-3566. 
(14) Guo, Y. Y.; Zhang, J.; Dong, L. Z.; Xu, Y.; Han, W.; Fang, M.; Liu, H. K.; Wu, Y.; Lan, Y. Q. Syntheses of Exceptionally Stable Aluminum (III) Metal-Organic Frameworks: How to Grow High-Quality, Large, Single Crystals. Chem. - Eur. J. 2017, 23 (61), 1551 8-15528.

(15) An, Y.; Liu, Y. Y.; An, P. F.; Dong, J. C.; Xu, B. Y.; Dai, Y.; Qin, X. Y.; Zhang, X. Y.; Whangbo, M. H.; Huang, B. B. NiII Coordination to an Al-Based Metal-Organic Framework Made from 2-Aminoterephthalate for Photocatalytic Overall Water Splitting. Angew. Chem., Int. Ed. 2017, 56 (11), 3036-3040.

(16) Wei, M. J.; Zhang, J. H.; Liao, W. M.; Wei, Z. W.; Pan, M.; Su, C. Y. A novel Co-O cluster based coordination polymer for efficient hydrogen production photocatalysis. $J$ Photoch Photobio A. 2020, 387, 112137.

(17) Yuan, S.; Qin, J. S.; Xu, H. Q.; Su, J.; Rossi, D.; Chen, Y. P.; Zhang, L. L.; Lollar, C.; Wang, Q.; Jiang, H. L.; Son, D. H.; Xu, H. Y.; Huang, Z H..; Zou, X. D.; Zhou, H. C. $\left[\mathrm{Ti}_{8} \mathrm{Zr}_{2} \mathrm{O}_{12}(\mathrm{COO})_{16}\right]$ Cluster: An ideal inorganic building unit for photoactive metal-organic frameworks. ACS Cent. Sci. 2018, 4 (1), 105-111.

(18) Samanta, D.; Verma, P.; Roy, S.; Maji, T. K. Nanovesicular MOF with Omniphilic Porosity: Bimodal Functionality for White-Light Emission and Photocatalysis by Dye Encapsulation. ACS Appl. Mater. Interfaces 2018, 10 (27), 23140-23146.

(19) Xiao, Y. J.; Guo, X. Y.; Liu, J. X.; Liu, L. F.; Zhang, F. X.; Li, C. Development of a bismuth-based metal-organic framework for photocatalytic hydrogen production. Chinese $J$ Catal. 2019, $40(9), 1339-1344$. 
(20) Dou, Y.; Yang, L.; Qin, L.; Dong, Y.; Zhou, Z.; Zhang, D.; Wang, S. Self-assembly of a cobalt (II)-based metal-organic framework as an effective water-splitting heterogeneous catalyst for light-driven hydrogen production. Acta Cryst. C 2020, 76 (6), 616-624.

(21) Yang, G. L.; Che, X. J.; Hou, S. L.; Cao, C. S.; Zhao, B. Photocatalytic Hydrogen Evolution Based on Cobalt-Organic Framework with High Water Vapor Adsorption. Inorg. Chem. 2021, 60 (3), 1922-1929.

(22) Chen, D. M.; Sun, C. X.; Liu, C. S.; Du, M. Stable layered semiconductive Cu(I)-organic framework for efficient visible-light-driven $\mathrm{Cr}(\mathrm{VI})$ reduction and $\mathrm{H}_{2}$ evolution. Inorg. Chem. 2018, 57 (13), 7975-7981.

(23) Guo, W. L.; Shu, S.; Zhang, T.; Jian, Y. F.; Liu, X. Stable d ${ }^{10}$ Metal-Organic Framework Exhibiting Bifunctional Properties of Photocatalytic Hydrogen and Oxygen Evolution. ACS Appl. Energy Mater. 2020, 3 (3), 2983-2988.

(24) Shi, D. Y.; Cui, C. J.; Hu, M.; Ren, A. H.; Song, L. B.; Liu, C. S.; Du, M. A microporous mixed-metal $(\mathrm{Na} / \mathrm{Cu})$ mixed-ligand (flexible/rigid) metal-organic framework for photocatalytic $\mathrm{H}_{2}$ generation. J. Mater. Chem. C 2019, 7 (33), 10211-10217.

(25) Kamakura, Y.; Chinapang, P.; Masaoka, S.; Saeki, A.; Ogasawara, K.; Nishitani, S. R.; Yoshikawa, H.; Katayama, T.; Tamai, N.; Sugimoto, K.; Tanaka, D. Semiconductive nature of lead-based metal-organic frameworks with three-dimensionally extended sulfur secondary building units. J. Am. Chem. Soc. 2019, 142 (1), 27-32. 
(26) Leng, F. C.; Liu, H.; Ding, M. L.; Lin, Q. P.; Jiang, H. L. Boosting photocatalytic hydrogen production of porphyrinic MOFs: the metal location in metalloporphyrin matters. Acs Catal. 2018, 8 (5), 4583-4590.

(27) Zhang, J. X.; Hu, W.; Zhang, J.; Liu, S. J.; Tong, J.; Hou, X. D.; Liu, W. L.; Yang, J. L.; Liu, B. Stable Heteropolyoxotitanate Nanocluster for Full Solar Spectrum Photocatalytic Hydrogen Evolution. J. Phys. Chem. C 2017, 121 (34), 18326-18332.

(28) Yu, Q.; Dong, H.; Zhang, X.; Zhu, Y. X.; Wang, J. H.; Zhang, F. M.; Sun, X. J. Novel stable metal-organic framework photocatalyst for light-driven hydrogen production. CrystEngComm 2018, 20 (23), 3228-3233.

(29) Assi, H.; Pardo Pérez, L. C.; Mouchaham, G.; Ragon, F.; Nasalevich, M.; Guillou, N.; Martineau, C.; Chevreau, H.; Kapteijn, F.; Gascon, J.; Fertey, P.; Elkaim, E.; Serre, C.; Devic, T. Investigating the case of titanium(IV) carboxyphenolate photoactive coordination polymers. Inorg. Chem. 2016, 55 (15), $7192-7199$.

(30) Horiuchi, Y.; Toyao, T.; Saito, M.; Mochizuki, K.; Iwata, M.; Higashimura, H.; Anpo, M.; Matsuoka, M. Visible-light-promoted photocatalytic hydrogen production by using an aminofunctionalized Ti(IV) metal-organic framework. J. Phys. Chem. C 2012, 116 (39), 20848-20853. 